\title{
Thomas Hodgkin and Hodgkin lymphoma
}

\author{
Judith A. Ferry
}

Received: 26 June 2014 / Accepted: 31 July 2014 /Published online: 12 August 2014

(C) Springer-Verlag Berlin Heidelberg 2014

\begin{abstract}
In 1832 Thomas Hodgkin, a physician at Guy's Hospital in London, published a description of seven cases of lymph nodes with unusual changes. Little did he suspect that this publication would lead to recognition of the now-familiar entity that has come to be known as Hodgkin lymphoma. In the years that have passed since that publication, diagnostic criteria and a straightforward system for subclassification of Hodgkin lymphoma have been established. The cell of origin for the characteristic neoplastic cell, the Reed-Sternberg cell, was identified after much scientific struggle. With improvements in therapy, the prognosis for Hodgkin lymphoma patients has improved remarkably; indeed, the development of effective treatment for Hodgkin lymphoma serves as a medical success story. Current investigation focuses on better understanding of the intricacies of the complex biology of Hodgkin lymphoma, including the genetic changes underlying its pathogenesis, and improving therapy for the minority of patients who do not respond well to currently available treatment.
\end{abstract}

Keywords Hodgkin lymphoma · Reed-Sternberg cell · Nodular lymphocyte predominant Hodgkin lymphoma . Classical Hodgkin lymphoma · Immunophenotype · Differential diagnosis

\section{Introduction}

The story of Hodgkin lymphoma began in 1832, when Thomas Hodgkin published a landmark paper entitled "On some morbid appearances of the absorbent glands and spleen" [1]. The name "Hodgkin's disease" was first applied to such cases by Sir Samuel Wilks in 1865 [2]. Carl Sternberg [3] and Dorothy Reed [4] each described the large atypical cells characteristic of

\section{J. A. Ferry $(\bowtie)$}

Department of Pathology, Massachusetts General Hospital, 55 Fruit

Street, Boston, MA 02114, USA

e-mail: jferry@partners.org
Hodgkin's disease; these distinctive cells thus became known as Reed-Sternberg cells. However, it was not until the middle of the twentieth century that Hodgkin's disease was clearly recognized as neoplastic; formerly, it was thought to be a reactive, likely infectious process, possibly related to tuberculosis. In the decades that followed, methods for treatment of Hodgkin's disease improved dramatically, so that this disease that had a $5 \%$ chance of long-term survival in the first half of the twentieth century now has a much more favorable prognosis, with approximately $85 \%$ of patients being cured of Hodgkin's disease [5].

Despite the marked improvement in outcome, Hodgkin's disease remained a biological enigma. It is a unique neoplasm in that the neoplastic cells often account for only $0.1-2 \%$ of all cells in the involved tissues [6]. In addition, despite the everincreasing availability of antibodies for use in immunohistochemical analysis, the origin of the Reed-Sternberg cell remained unknown for many years. Origins from T cells, B cells, histiocytes, follicular dendritic cells, myeloid cells, and others were suggested, but the cell of origin remained elusive. It was not until the 1990s that the cell of origin was demonstrated to be the B lymphocyte [7], and Hodgkin's disease is now accepted as a form of B-lineage lymphoma with unique features. The term Hodgkin lymphoma has been adopted in preference to Hodgkin's disease in the WHO Classification because the neoplastic cells have been firmly established as being of lymphoid origin.

Subsequent advances in the study of Hodgkin lymphoma include documentation of genetic abnormalities contributing to its pathogenesis, evaluation of the characteristic microenvironment and its effect on prognosis $[8,9]$, and development of novel therapies to further improve the prognosis of Hodgkin lymphoma and to decrease the complications of treatment [6].

\section{Classification of Hodgkin lymphoma}

The WHO Classification of Hodgkin lymphoma includes two main categories: nodular lymphocyte predominant Hodgkin lymphoma and classical Hodgkin lymphoma. Under the 
heading of classical Hodgkin lymphoma are nodular sclerosis, mixed cellularity, lymphocyte-rich classical, and lymphocytedepleted subtypes (Table 1) [5]. There are a number of features that are common to nodular lymphocyte predominant and classical Hodgkin lymphoma: Disease arises in lymph nodes in nearly all cases; patients are younger, on average, than nonHodgkin lymphoma patients; the disease has a favorable prognosis and is almost always treatable; reactive cells typically outnumber neoplastic cells; neoplastic cells are of B cell origin in both categories; and neoplastic cells are usually surrounded by $\mathrm{T}$ cells $[5,10]$.

\section{Nodular lymphocyte predominant Hodgkin lymphoma}

Nodular lymphocyte predominant Hodgkin lymphoma (NLPHL) comprises $5 \%$ of all cases of Hodgkin lymphoma. Among prepubertal children, it accounts for a higher proportion of Hodgkin lymphomas [11, 12]. There is a male/female ratio of 3:1. This disorder affects patients over a wide age range with a median in the 30 s and a unimodal age distribution, in contrast to the bimodal age distribution of classical Hodgkin lymphoma. The typical presentation is with localized disease involving peripheral lymph nodes, most often cervical, followed by axillary and then by inguinal nodes. Typically, there are long disease-free intervals, but relapses are common. This is an indolent disease with excellent survival in most cases, and the intermittent isolated relapses are not usually associated with poor overall survival [10,12]. Patients who present with high-stage disease typically do not have a favorable outcome $[12,13]$. Bone marrow involvement is quite uncommon; it appears to be found only when there is other clinical or pathologic evidence of aggressive disease [14].

Histologic examination in cases of NLPHL reveals a lymph node that is replaced by an infiltrate that is entirely or partially nodular. The nodules are large, poorly circumscribed and expansile, and they contain scattered large neoplastic cells called lymphocytic and histiocytic cells (L\&H cells, because of the composition of the cellular background), popcorn cells (because of the frequently lobated shape of the nucleus of the neoplastic cells), and most recently lymphocyte-predominant cells (LP cells) [10]. The characteristic phenotype of LP cells is CD20+ bcl6+, CD15-, CD30-, CD45+ Oct-2+ (bright), BOB.1+, and Epstein-Barr virus-negative (Fig. 1). In occasional cases, the LP cells express CD30, but the CD30 is usually weak and expressed by only a subset of the neoplastic cells [15]. A subset of NLPHL has IgD+ LP cells $(27 \%$ in one large series) [16]. The authors found a number of clinical and pathological features correlating with $\operatorname{IgD}$ expression: $\operatorname{IgD}+$ cases affected younger patients (median age of 21 vs 44 years for IgD- cases), higher male/female ratio (23:1 vs $1.5: 1$ ), more frequent involvement of cervical lymph nodes (56 vs
Table 1 WHO classification of Hodgkin lymphoma
Nodular lymphocyte predominant Hodgkin lymphoma
Classical Hodgkin lymphoma
Nodular sclerosis classical Hodgkin lymphoma
Mixed cellularity classical Hodgkin lymphoma
Lymphocyte-rich classical Hodgkin lymphoma
Lymphocyte-depleted classical Hodgkin lymphoma

From Stein et al. [5]

$18 \%$ ), and frequent extranodular localization of IgD $+\mathrm{LP}$ cells (69 \% of cases). Although traditionally, the LP cells are described as negative for Epstein-Barr virus (EBV), in rare cases (3\% in one large series), LP cells may harbor EBV [17]. When single LP cells have been extracted and subjected to polymerase chain reaction, they are shown to be clonal with ongoing mutation of the immunoglobulin variable region genes $[6,18]$, analogous to the non-neoplastic germinal center cell. The normal counterpart of the LP cell is believed to be the centroblast (large non-cleaved cell) of the germinal center.

The genetic features of NLPHL show some overlap with those of classical Hodgkin lymphoma (see below). There is evidence of activation of both nuclear factor-kappa B (NF-kB) and Janus kinase/signal transducer and activator of transcription (JAK/STAT) signaling pathways; inactivating mutations of suppressor of cytokine signaling 1 (SOCS1) have been documented that are believed to contribute to JAK/STAT activation [12].

Reactive cells are an important component of the nodules of NLPHL, and they include lymphocytes, histiocytes, and follicular dendritic cells. The lymphocytes in most cases are predominantly B cells with an admixture of $\mathrm{T}$ cells (CD4> CD8). T cells tend to cluster around the LP cells. There are often increased numbers of CD57+ T cells within these nodules and sometimes CD57+ T cell rosette around the LP cells. T cells clustered around LP cells consistently express PD1, a marker of $T$ follicular helper cells [19]. By flow cytometry, a double-positive (CD4+ CD8+) T cell population can be found in some cases of NLPHL, typically constituting a minority of the $\mathrm{T}$ cells. In contrast to $\mathrm{T}$ lymphoblasts, these $\mathrm{T}$ cells are negative for CD1a and TdT, and they are otherwise immunophenotypically normal. The presence of a CD4+ CD8+ T cell population in NLPHL may reflect an activated or reactive $\mathrm{T}$ cell subset and should not lead to a misdiagnosis of T cell lymphoma [20]. Nodules are delimited by expanded, somewhat disrupted networks of follicular dendritic cells.

Rare cases of NLPHL contain background T cells with prominent cytologic atypia, raising the differential diagnosis of peripheral T cell lymphoma not otherwise specified (PTCLNOS) or composite lymphoma. Atypical T cells are found surrounding primary and secondary follicles in a pattern mimicking the T-zone pattern of PTCL-NOS; less frequently, 

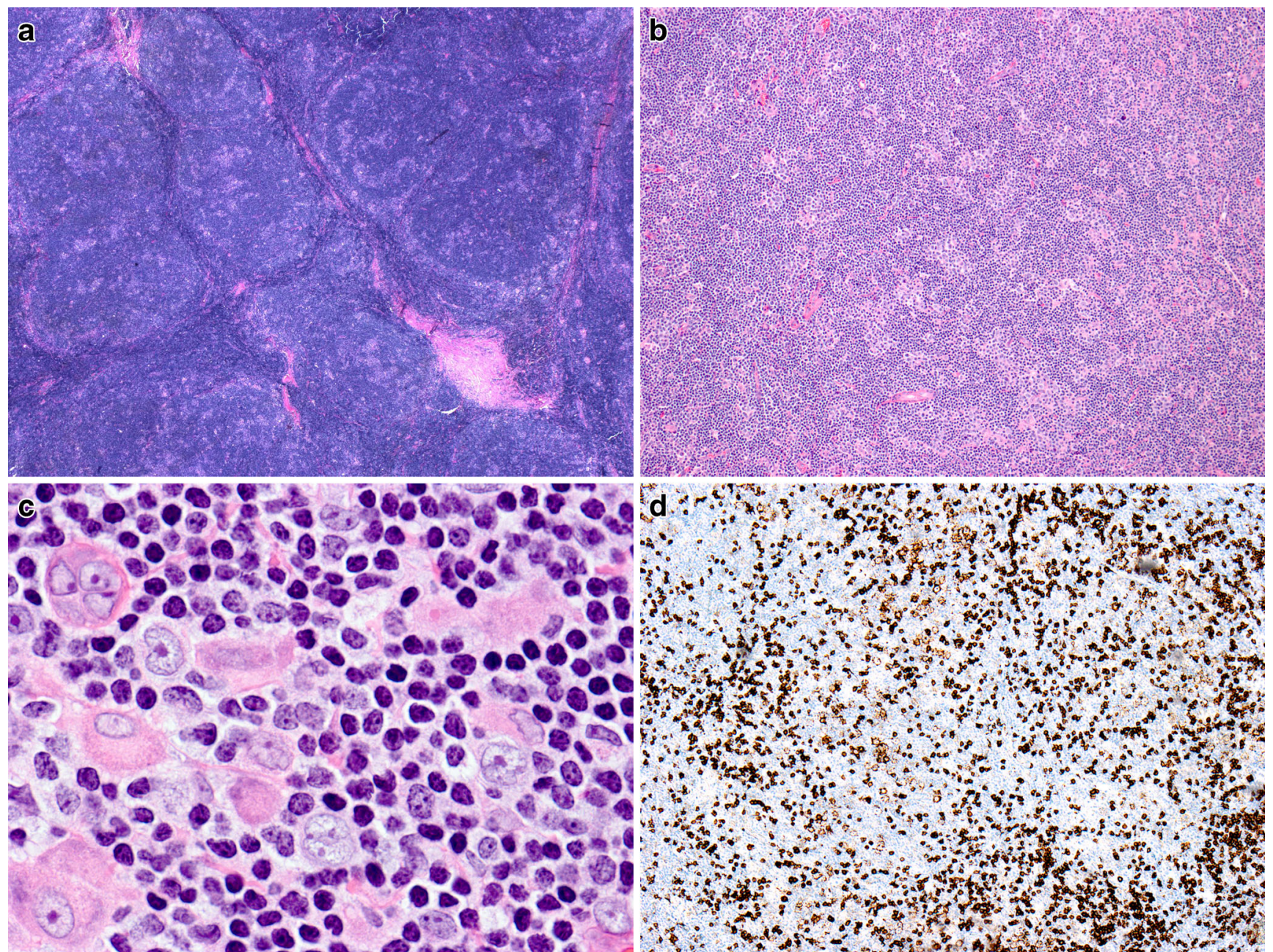

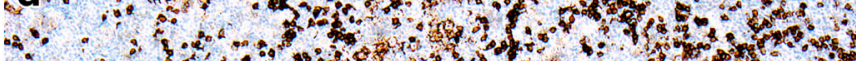

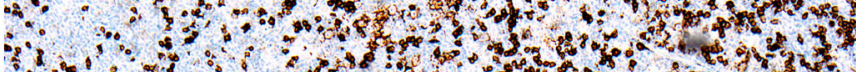

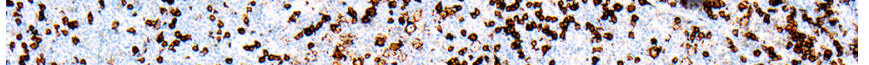

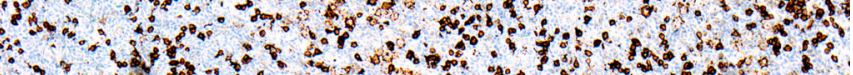

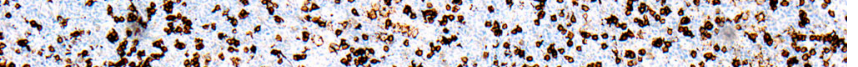

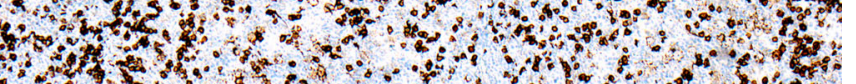

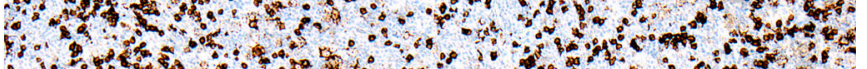

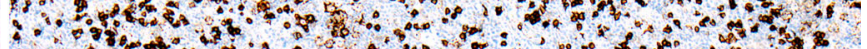

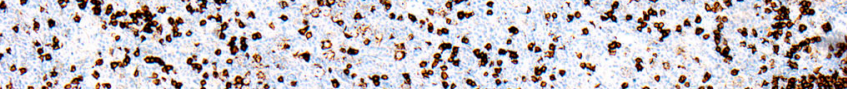

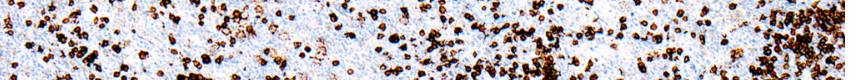
:

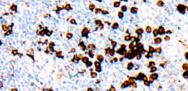

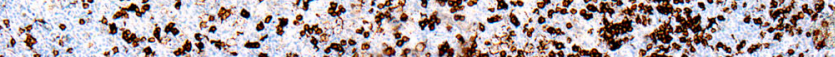

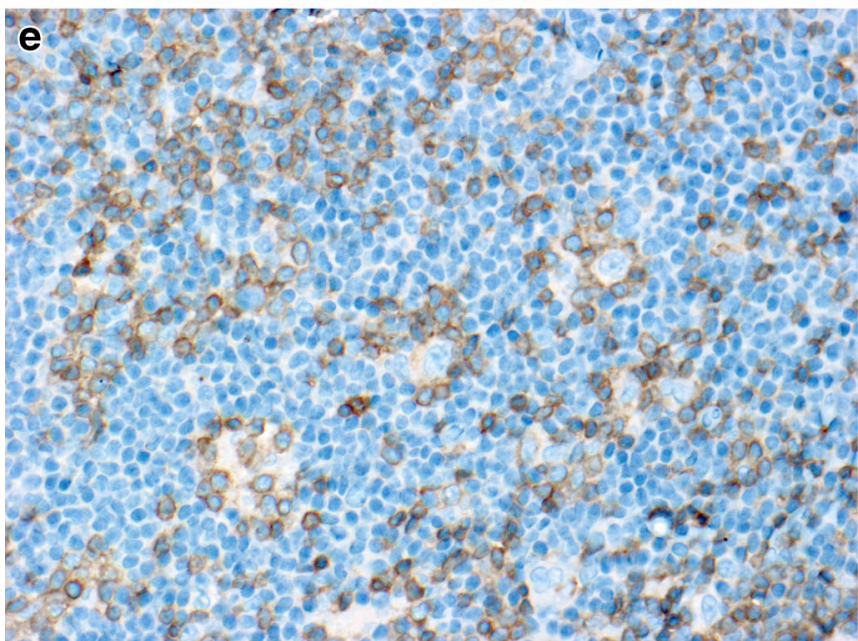

Fig. 1 Nodular lymphocyte predominant Hodgkin lymphoma. a Low power shows an enlarged lymph node replaced by multiple large, crowded expansile nodules of lymphoid cells. b A single poorly delineated mottled-appearing nodule of larger cells scattered on a background of many small lymphocytes is seen. c High power shows a few large atypical LP cells with large, pale, oval, indented, or lobated nuclei; small

atypical T cells form large clusters at the periphery of B cellrich nodules of NLPHL. Scattered LP cells can be found nucleoli; and scant cytoplasm scattered in a background of small lymphocytes and histiocytes with abundant pink cytoplasm. d An immunostain for CD20 shows staining of many small B cells and scattered large LP cells in one nodule. e An immunostain for CD3 shows multiple T cell rosettes around LP cells

within the atypical $\mathrm{T}$ cell-rich areas in all cases. The atypical $\mathrm{T}$ cells have a variable immunophenotype, but they show no 
immunophenotypic abnormality diagnostic of T cell lymphoma, and PCR discloses no clonal $\mathrm{T}$ cell population. These cases appear to behave in a manner similar to that of NLPHL with $\mathrm{T}$ cell-rich diffuse areas, i.e., with a higher risk of disease recurrence than in cases of NLPHL with a classic appearance (see below) [21].

In addition to the classic pattern, some cases have variant patterns: (1) The nodules may contain small cells that are predominantly $\mathrm{T}$ cells (the T cell-rich nodular pattern); (2) LP cells may be found around but outside the nodules, outside the follicular dendritic cell network (nodular with prominent extranodular LP cell pattern); (3) nodules may be serpiginous and interconnected (serpiginous/interconnected nodular pattern); (4) nodularity can be vague and difficult to appreciate but with a B cell-rich background (diffuse B cell-rich pattern); or (5) there may be diffuse areas with small cells that are mostly $\mathrm{T}$ cells, resembling $\mathrm{T}$ cell-rich large $\mathrm{B}$ cell lymphoma (T cell-rich large B cell-like pattern).

When variant patterns were first described, it was noted that the presence of a T cell-rich B cell lymphoma (TCRBCL)like component may indicate a higher risk for recurrence [22]. In addition, it was noted that there may be a tendency for NLPHL to progress over time to having a more diffuse pattern [22]. The prognostic importance of the variant patterns has recently been the focus of additional study. For cases of NLPHL with a component of variants characterized by depletion of small B cells in nodules or by presence of neoplastic cells outside nodules ( $T$ cell-rich nodular pattern, TCRBCLlike pattern, prominent extranodular LP cells, and diffuse B cell-rich pattern), a greater likelihood of advanced stage disease and a higher risk of relapse have been reported [23].

In a subset of cases, there is an associated diffuse large B cell lymphoma (DLBCL) that appears to represent outgrowth of the neoplastic cells of the original Hodgkin lymphoma [24]. The diffuse large B cell lymphoma may be found after, concurrent with, or rarely, before the NLPHL [22, 25]. Among patients presenting initially with NLPHL alone, the frequency of progression to DLBCL has varied widely among series. However, histologic progression may occur many years after initial diagnosis of NLPHL, and in studies with long followup, cases with progression are not rare. In one large series, the risk of progression to an aggressive lymphoma was $7 \%$ at 10 years and $30 \%$ at 20 years [26].

Transformation appears to be more common in patients who present initially with NLPHL with advanced stage with splenic involvement $[12,26]$. These diffuse large B cell lymphomas may present in lymph nodes or extranodal sites [25]. The majority is described only as DLBCL, while a minority is described as T cell/histiocyte-rich large B cell lymphoma. At transformation, the majority of patients have B symptoms, high-stage disease, splenic involvement, and elevated LDH [26]. They are moderately aggressive, with behavior similar to that of diffuse large B cell lymphoma arising de novo [25]. In one series, the 10 -year progression-free survival was $52 \%$, and the 10-year overall survival was $62 \%$ in patients with transformed lymphoma [26].

Nodular lymphocyte-predominant Hodgkin lymphoma: differential diagnosis

The differential diagnosis of NLPHL includes non-specific reactive lymphoid hyperplasia, reactive hyperplasia with progressive transformation of germinal centers, follicular lymphoma, lymphocyte-rich classical Hodgkin lymphoma, T cell/ histiocyte-rich large B cell lymphoma, and T cell lymphomas (Table 2).

Non-specific reactive lymphoid hyperplasia is an important entity in the differential diagnosis of NLPHL. Nodularity may be vague on low power examination of NLPHL, characteristic LP cells are infrequent, and flow cytometry discloses no diagnostic evidence of lymphoma. The most efficient way to make a diagnosis is to note the large, expansile, ill-defined nodules of lymphoid cells and to consider the possibility of NLPHL on low power examination. Once the diagnosis of NLPHL is considered, it is fairly straightforward to search within nodules on higher power for LP cells and to obtain immunostains to highlight the LP cells and the characteristic reactive cells, in order to establish a diagnosis.

Reactive hyperplasia with prominent progressive transformation of germinal centers (PTGC) can raise the question of NLPHL. In PTGC mantle zone-type B cells infiltrate and replace the germinal center and enlarge the follicle, so that the enlarged follicles of PTGC can superficially resemble nodules of NLPHL. NLPHL, however, results in architectural distortion due to a proliferation of multiple large, poorly circumscribed nodules and shows convincing LP cells surrounded by $\mathrm{T}$ cell rosettes. The presence of reactive follicles of the usual type interspersed among PTGCs strongly favors reactive hyperplasia [27]. NLPHL can also mimic lowgrade follicular lymphoma, although neoplastic follicles tend to be better delineated than the nodules of NLPHL, neoplastic follicle center cells should be at least slightly larger than most small cells in NLPHL, and neoplastic follicle center cells typically express CD10 and/or bcl6 and bcl2. Submitting material for flow cytometry facilitates establishing a diagnosis, as follicular lymphoma, but not NLPHL, harbors a monotypic B cell population detectable by flow cytometry.

In contrast to classical Hodgkin lymphoma, findings that are infrequent or absent in NLPHL are granulocytes, plasma cells, classic Reed-Sternberg cells, sclerosis, and necrosis. Lymphocyte-rich classical Hodgkin lymphoma has a background similar to that of NLPHL. It is the type of Hodgkin lymphoma most difficult to distinguish from NLPHL, and immunophenotyping is recommended to make a definitive diagnosis (see below, "Lymphocyte-rich classical Hodgkin lymphoma" section) $[13,28]$. 
Table 2 Nodular lymphocyte-predominant Hodgkin lymphoma: differential diagnosis

\begin{tabular}{|c|c|c|}
\hline Diagnosis & Problem & Clues to diagnosis \\
\hline $\begin{array}{l}\text { Reactive lymphoid } \\
\text { hyperplasia (RLH) }\end{array}$ & $\begin{array}{l}\text { LP calls can be rare and inconspicuous; if overlooked, } \\
\text { NLPHL can be mistaken for reactive hyperplasia }\end{array}$ & $\begin{array}{l}\text { NLPHL often shows marked nodal enlargement, marked } \\
\text { architectural distortion; look for LP cells in the large } \\
\text { expansile nodules }\end{array}$ \\
\hline $\begin{array}{l}\text { RLH with progressive } \\
\text { transformation of } \\
\text { germinal centers (PTGC) } \\
\text { [27] }\end{array}$ & $\begin{array}{l}\text { Appearance of PTGC overlaps with individual nodules of } \\
\text { NLPHL }\end{array}$ & $\begin{array}{l}\text { PTGCs are scattered among reactive follicles; NLPHL causes } \\
\text { more prominent architectural distortion. PTGCs lack } \\
\text { convincing LP cells, and PD1+ T cell rosettes are rare }\end{array}$ \\
\hline Follicular lymphoma (FL) & $\begin{array}{l}\text { FL and NLPHL both produce a nodular pattern, usually } \\
\text { with architectural effacement }\end{array}$ & $\begin{array}{l}\text { FL has a component of centrocytes (small cleaved cells), } \\
\text { lacks LP cells, and contains clonal B cells on flow } \\
\text { cytometry; NLPHL has LP cells in a background of small } \\
\text { polytypic B cells and T cells and lacks a component of } \\
\text { centrocytes; no clonal B cells are found by flow cytometry }\end{array}$ \\
\hline \multirow{4}{*}{$\begin{array}{l}\text { T cell/histiocyte-rich large B } \\
\text { cell lymphoma } \\
\text { (THRBCL) [29-32] }\end{array}$} & \multirow{4}{*}{$\begin{array}{l}\text { NLPHL and THRBCL both have large atypical bcl6+ B } \\
\text { cells in a background of small lymphocytes and } \\
\text { histiocytes }\end{array}$} & $\begin{array}{l}\text { NLPHL is at least partially nodular, by definition; THRBCL } \\
\text { is entirely diffuse }\end{array}$ \\
\hline & & $\begin{array}{l}\text { Making a distinction on a small biopsy can be difficult } \\
\text { because of sampling artifact, so obtaining a larger biopsy } \\
\text { can be helpful }\end{array}$ \\
\hline & & $\begin{array}{l}\text { Background lymphocytes in THRBCL are almost } \\
\text { exclusively T cells; B cells are rare, in contrast to NLPHL }\end{array}$ \\
\hline & & $\begin{array}{l}\text { THRBCL more often presents with high-stage disease than } \\
\text { NLPHL, so clinical features may be helpful }\end{array}$ \\
\hline $\begin{array}{l}\text { T lymphoblastic lymphoma } \\
\text { (T-LBL) [20] }\end{array}$ & $\begin{array}{l}\text { Flow cytometry in some cases of NLPHL shows a CD4/ } \\
\text { CD8 double-positive T cell population, raising question } \\
\text { of T lymphoblastic lymphoma }\end{array}$ & $\begin{array}{l}\text { The CD4+/CD8+ T cells are negative for CD1a and TdT; } \\
\text { features are typical of NLPHL and do not otherwise } \\
\text { suggest T-LBL }\end{array}$ \\
\hline \multirow[t]{2}{*}{$\begin{array}{l}\text { Peripheral T cell lymphoma } \\
\text { (PTCL) [21] }\end{array}$} & \multirow[t]{2}{*}{$\begin{array}{l}\text { Rare cases of NLPHL have an atypical-appearing T cell } \\
\text { component that can suggest PTCL (or composite lym- } \\
\text { phoma with NLPHL and PTCL) }\end{array}$} & $\begin{array}{l}\text { The atypical T cells in cases of NLPHL show no diagnostic } \\
\text { immunophenotypic abnormality and have no detectable } \\
\text { clonality by molecular studies }\end{array}$ \\
\hline & & $\begin{array}{l}\text { PTCL should be diagnosed with extreme caution in the } \\
\text { presence of areas of NLPHL }\end{array}$ \\
\hline
\end{tabular}

T cell/histiocyte-rich large B cell lymphoma can be included in the differential with NLPHL. Comparison of the small reactive cells, the large neoplastic cells, and the pattern of growth may be helpful in distinguishing these two disorders. In NLPHL, the large cells are LP cells, and in T cell/histiocyterich large B cell lymphoma, they may have a similar appearance, but they may also resemble centroblasts or immunoblasts or be bizarre. Their immunophenotype is nearly identical, with only minor differences. IgD expression on LP cells is more common than on the neoplastic cells of T cell/ histiocyte-rich large B cell lymphoma (27 vs $5 \%$ ), for example [16]. NLPHL by definition has an architecture that is at least partially nodular. T cell/histiocyte-rich large B cell lymphoma is typically diffuse but may show vague nodularity on routinely stained sections; follicular dendritic cell meshworks as seen in NLPHL are absent, however [29]. In T cell/ histiocyte-rich large B cell lymphoma, the background cells are almost all $\mathrm{T}$ cells with hardly any small $\mathrm{B}$ cells. T cell/ histiocyte-rich large B cell lymphoma is reported to have a higher proportion of $\mathrm{CD} 8+\mathrm{T}$ cells and TIA1 $+\mathrm{T}$ cells than NLPHL in some studies $[10,30]$. T cell/histiocyte-rich large B cell lymphoma is also reported to have a lower proportion of
CD4+ $\mathrm{T}$ cells and of $\mathrm{T}$ cells with a $\mathrm{T}$ follicular helper cell phenotype than NLPHL [31]. Staining for the $T$ follicular helper cell marker PD1 may be helpful, as PD1+ T cells do not form rosettes around large neoplastic B cells in typical cases of T cell/histiocyte-rich large B cell lymphoma [19]. Such rosettes are also typically absent in T cell/histiocyte-rich, diffuse areas of NLPHL, limiting the usefulness of this feature in such cases [31]. Diffuse areas of NLPHL can be very difficult to distinguish from $T$ cell/histiocyte-rich large $B$ cell lymphoma, so caution should be exercised when considering a diagnosis of $\mathrm{T}$ cell/histiocyte-rich large $\mathrm{B}$ cell lymphoma on a needle biopsy specimen. Adding a comment to the diagnostic report indicating this issue and suggesting obtaining a larger biopsy specimen, if clinically indicated, can be considered. It is possible to speculate that cases in which a diagnosis of $\mathrm{T}$ cell/histiocyte-rich large B cell lymphoma is made initially and in which a subsequent biopsy shows NLPHL, represent NLPHL with diffuse areas, in which the characteristic nodular foci were not sampled in the initial biopsy specimen.

The difficulty in distinguishing $\mathrm{T}$ cell/histiocyte-rich large B cell lymphoma, NLPHL, and NLPHL with T cell/histiocyte-rich diffuse areas is underscored by molecular 
analysis, as the neoplastic cells of these entities are not readily separable by gene expression profile [31]. Interestingly, differences in the composition of the microenvironment are better defined than differences in neoplastic cells of $\mathrm{T}$ cell/histiocyte-rich large B cell lymphoma and NLPHL [31]. The possibility that $\mathrm{T}$ cell/histiocyte-rich large $\mathrm{B}$ cell lymphoma represents transformation or progression of NLPHL has been suggested; however, comparative genomic hybridization shows that the neoplastic cells of T cell/histiocyte-rich large B cell lymphoma have fewer genomic imbalances than NLPHL, excluding that hypothesis. Certain abnormalities are common in both types of lymphoma, including changes affecting X, 4q, and $17 \mathrm{p}$, suggesting that these two lymphomas do share some pathogenetic features or possibly a common cell of origin [32]. It may be that $\mathrm{T}$ cell/histiocyte-rich large B cell lymphoma and NLPHL represent a biological spectrum, with differences in microenvironment, rather than differences in neoplastic cells, driving the behavior of these lymphomas [31].

$\mathrm{T}$ cell lymphomas may enter the differential diagnosis of NLPHL if flow cytometry reveals a very high CD4/CD8 ratio or a $\mathrm{CD} 4 / \mathrm{CD} 8$ double-positive $\mathrm{T}$ cell population or if there is an associated atypical $\mathrm{T}$ cell population, as noted above. Familiarity with the spectrum of characteristics of $\mathrm{T}$ cells associated with NLPHL will help to avoid misdiagnosis.

\section{Classical Hodgkin lymphoma}

Classical Hodgkin lymphoma (CHL) shows a bimodal age distribution with peaks among young adults and among the elderly in developed countries. In developing countries, the early peak affects children, rather than young adults. Most patients present with localized (stage I or stage II) disease; occasional patients present with widespread disease. This is a moderately aggressive lymphoma, but it is curable in most cases. The prognosis has improved dramatically in the last 70 years. The hallmark of CHL is the Reed-Sternberg cell, a neoplastic cell with distinctive morphology and immunophenotype that must be present in the appropriate cellular background to establish a diagnosis of CHL. The Reed-Sternberg cell is large, with two or more large, oval or irregular nuclei (or nuclear lobes) each containing an eosinophilic nucleolus surrounded by a perinucleolar halo. Uninucleate cells with similar features are known as mononuclear variants. These neoplastic cells are $\mathrm{CD} 30+$, usually $\mathrm{CD} 15+$, negative for most $\mathrm{B}$ cell markers, typically negative for $\mathrm{T}$ cell markers, negative for immunoglobulin, negative for CD45, and negative for anaplastic lymphoma kinase (ALK). These cells do usually express BSAP (Pax5), B cell-specific activator protein, often less intensely than admixed B lymphocytes (Fig. 2). In occasional cases, B cell-associated markers other than Pax5, such as CD20, are expressed by the neoplastic cells, but in such cases, B antigen expression is variably intense, often weak, and is found on only a subset of tumor cells. Neoplastic cells lack Oct-2, a transcription factor for immunoglobulin, or BOB.1, a co-activator of Oct-2, or both of these proteins that are normally expressed in B cells [5].

In a small proportion of cases (5\% in one analysis) [33], there is expression of one or more $\mathrm{T}$ cell antigens by neoplastic cells. T antigen + cases of CHL were most often nodular sclerosis type in one large series [34]; of these, most had an abundance of tumor cells, consistent with NS2 morphology. Among T antigens investigated, CD2 and CD4 were those most commonly expressed by neoplastic cells. Less commonly expressed were CD3, CD5, CD7, and CD8 (Fig. 2e) [34]. Expression of more than one $\mathrm{T}$ cell-associated antigen on tumor cells was common. Only a minority of neoplastic cells expressed any one $\mathrm{T}$ cell antigen (10 to $35 \%$ in one series). Staining was usually in a membrane pattern; "blob-like" staining in a Golgi pattern was found less commonly. T antigen+ Hodgkin lymphoma is typically negative for EBV. Clonal T cell receptor gene rearrangement has been documented rarely, but in general, TCR genes are in the germline configuration in these cases [34]. T antigen expression has been associated with shorter overall and event-free survival [34].

Epstein-Barr virus (EBV) is present in the neoplastic cells in approximately $40 \%$ of cases. The neoplastic cells express EBV latent membrane protein, corresponding to the latency II pattern of EBV latent antigen expression. In situ hybridization shows that $\mathrm{EBV}+$ cells are positive for EBV-encoded RNA or EBER and in cases so analyzed that the EBV DNA is in the clonal episomal form [35]. EBV is found in the majority of cases of mixed cellularity type of Hodgkin lymphoma and is more common in Hodgkin lymphoma in young children and older adults than in young adults $[36,37]$.

The reactive cells of CHL are also an important component of the disorder, helping to define its microscopic features and helping to distinguish it from non-Hodgkin lymphomas. Characteristically, there are many small lymphocytes with $\mathrm{T}$ cells usually outnumbering B cells, as well as variable numbers of admixed histiocytes, plasma cells, eosinophils, and neutrophils. Sclerosis and necrosis are variably present. Architectural effacement may be complete or partial. Occasional cases show an interfollicular distribution that on low-power examination could mimic reactive hyperplasia.

The reactive component or the microenvironment of CHL is not only useful in facilitating diagnosis but also plays an integral, active role in the pathogenesis of the disease. This component of the disease has been studied using immunohistochemistry as well as gene expression profiling in recent years, with generation of an enormous amount of novel data. The various cells in the microenvironment are thought to be recruited by chemokines and cytokines secreted by ReedSternberg cells and variants. Some of the reactive cells in turn stimulate the neoplastic cells to survive and proliferate and to 

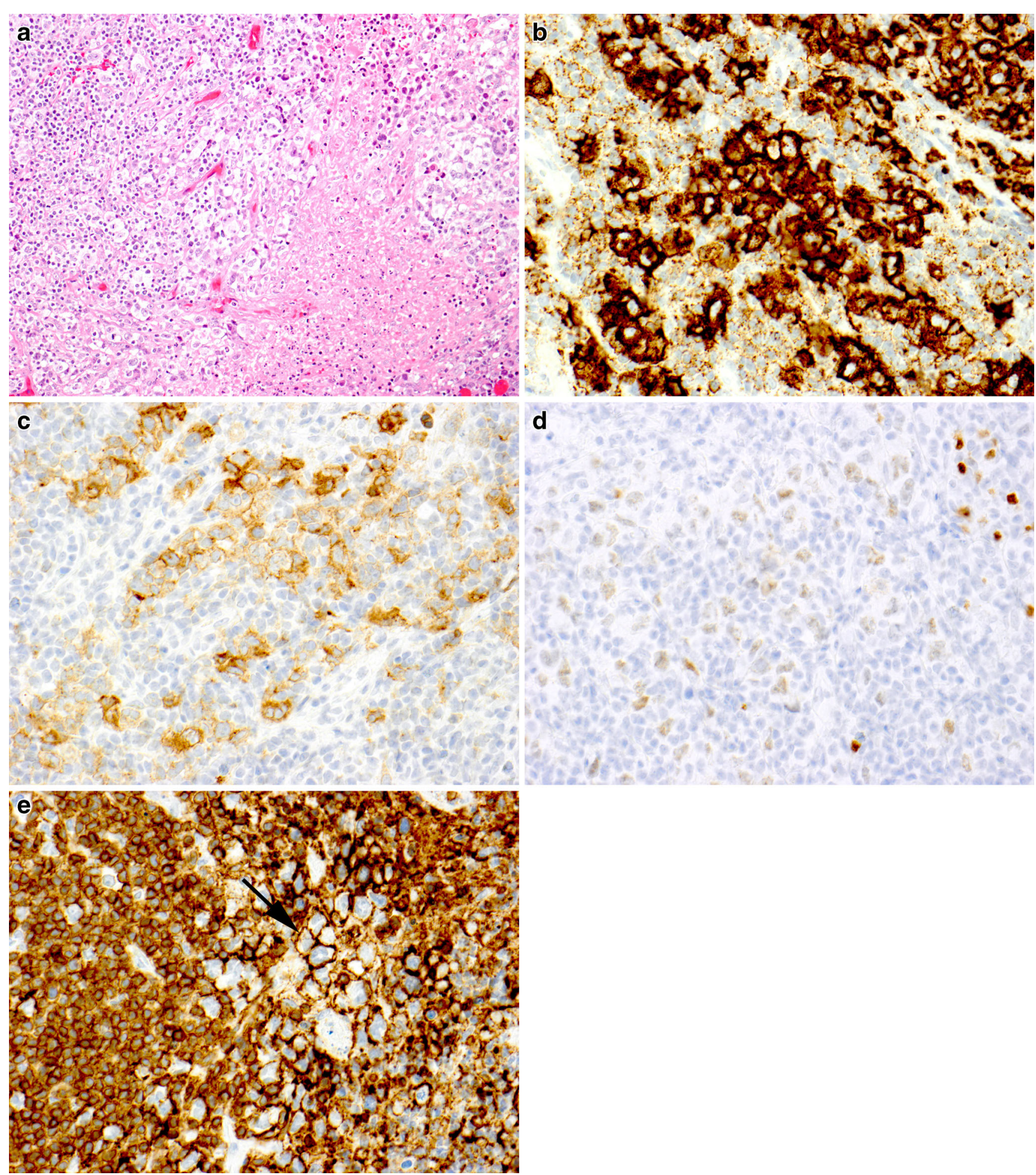

Fig. 2 Nodular sclerosis classical Hodgkin lymphoma with T antigen expression. a Neoplastic cells, many with the morphology of lacunar cells, are concentrated around an area of necrosis. Neutrophils are scattered in the necrotic material. b-d Neoplastic cells are CD15+ (b), CD30+ (c), and Pax 5 dim+ (d). e Neoplastic cells focally express CD3

evade elimination by the immune response [8]. In addition, the composition of the microenvironment may be of (arrow) as well as CD4 (not shown). Most of the surrounding small lymphocytes are also CD3+ T cells. The immunophenotype was otherwise typical for NSCHL, and no clonal T cell population was detected by PCR

prognostic importance. It has been proposed that cases of $\mathrm{CHL}$ with a larger component of macrophages have shortened 
survival compared to those with fewer macrophages [9]. Given the importance of the microenvironment in the biology of Hodgkin lymphoma, it has received attention as a potential therapeutic target, with the idea that if the activating, supporting milieu characteristic of the disease is eliminated, the neoplastic cells may not be able to survive [8].

Southern blot hybridization studies have usually shown the immunoglobulin heavy chain gene (IGH@) in germline configuration although occasionally clonal rearrangements are demonstrated. The $\mathrm{T}$ cell receptor genes are almost always in the germline configuration. Kuppers and co-workers evaluated the status of IGH@ by PCR in single neoplastic cells selected from sections involved by Hodgkin lymphoma and found that the tumor cells had clonally rearranged IGH@, finally demonstrating definitively a B lymphocyte origin for Reed-Sternberg cells [7]. This remarkable observation was confirmed in other studies [6,38], Single-cell PCR shows that the neoplastic cells in most cases are clonal B cells with highly mutated immunoglobulin variable region genes [5-7].

Putting together the information on the immunophenotype and genotype of the Reed-Sternberg cells, the cell of origin of the Reed-Sternberg cell is established as a B cell at the germinal center or post-germinal center stage of differentiation that either has crippling mutations that prevent immunoglobulin expression or has defective immunoglobulin transcription apparatus that prevents immunoglobulin transcription. The presence of EBV in a substantial number of cases suggests that the virus may be important in the pathogenesis of a subset of CHL.

More recent studies have focused on the genetic abnormalities that may underlie the pathogenesis of Hodgkin lymphoma; better understanding of these abnormalities may help to identify effective targeted therapies for Hodgkin lymphoma. NF-KB pathway activation is typically found; on sections, this can be documented by demonstrating nuclear cREL and bright cytoplasmic TRAF1 expression [39]. The JAK/STAT signaling pathway is also often activated in CHL [6]. Mutations in SOCS1 are also common; SOCS1 can serve as an inhibitor of STAT, so that SOCS1 mutations may contribute to the pathogenesis of Hodgkin lymphoma via JAK/STAT pathway activation [40]. Deregulated activity of the PI3K/Akt pathway and the MAPK/ERK pathway is also described in association with Hodgkin lymphoma [6]. Recently, changes in microRNA expression have been recognized in ReedSternberg cells and variants compared to normal B cells. The significance of some of these changes is uncertain, but at least, some of them may be pathogenetically important. miR135a, for example, appears to promote upregulation of its target gene $J A K 2$, another factor that may contribute to activation of the JAK/STAT pathway [41].

The cytogenetic features of CHL have been studied by routine karyotyping and also by comparative genomic hybridization. Hodgkin lymphoma is associated with frequent aneuploidy and polyploidy. Comparative genomic hybridization discloses multiple cytogenetic abnormalities, both gains and losses, although without a consistent recurrent cytogenetic abnormality that is characteristic of this neoplasm [5, 42]. Fifteen percent of CHLs harbor a translocation involving the major histocompatibility complex class II transactivator (CIITA) [43], resulting in a modification which could potentially help the neoplastic cells evade elimination by the immune response. Chromosomal gains sometimes involve regions containing genes resulting in upregulation of signaling pathways thought to be important in the pathogenesis of Hodgkin lymphoma. Gains of 9p, the site of $J A K 2$, and of $2 \mathrm{p}$, the site of the REL oncogene involved in NF- $\mathrm{KB}$ activation, for example, are common [5, 11, 42].

Nodular sclerosis classical Hodgkin lymphoma

Nodular sclerosis classical Hodgkin lymphoma (NSCHL) accounts for approximately $70 \%$ of CHLs in developed countries. It mainly affects adolescents and young adults with females at least as often affected as males. In most cases, patients present with supradiaphragmatic disease that is Ann Arbor stage I or II. The mediastinum is often involved. On histologic examination, there are cellular nodules containing Reed-Sternberg cells and mononuclear variants and a variable admixture of reactive cells. The lacunar cell, with its distinctive cytoplasmic retraction forming a "little lake" around the cell, is the mononuclear variant characteristic of NSCHL. Fibrous bands separate the cellular nodules (Fig. 3a-c). EBV is found in only a minority of cases [44].

Subtypes of NSCHL include the cellular phase, in which there is a diffuse infiltrate without fibrous bands, and the socalled syncytial variant in which neoplastic cells are abundant and grow in sheets. The syncytial variant may be difficult to distinguish from non-Hodgkin lymphoma and carcinoma on routinely stained sections. NSCHL with few or moderate numbers of neoplastic cells have been called grade I, or NS1, while cases with numerous neoplastic cells have been designated as grade II, or NS2 (defined in the WHO Classification as $>25 \%$ of nodules having $>1$ hpf occupied by sheets of neoplastic cells). With optimal therapy, most investigators believe that grade does not have a significant impact on prognosis $[45,46]$.

Differential diagnosis of nodular sclerosis classical Hodgkin lymphoma

The most important entity in the differential diagnosis of NSCHL is diffuse large B cell lymphoma, in particular, primary mediastinal (thymic) large B cell lymphoma.

Mediastinal large $B$ cell lymphoma primarily affects young and middle-aged adults with a female preponderance [47-54]. Patients typically have symptoms related to the presence of a 

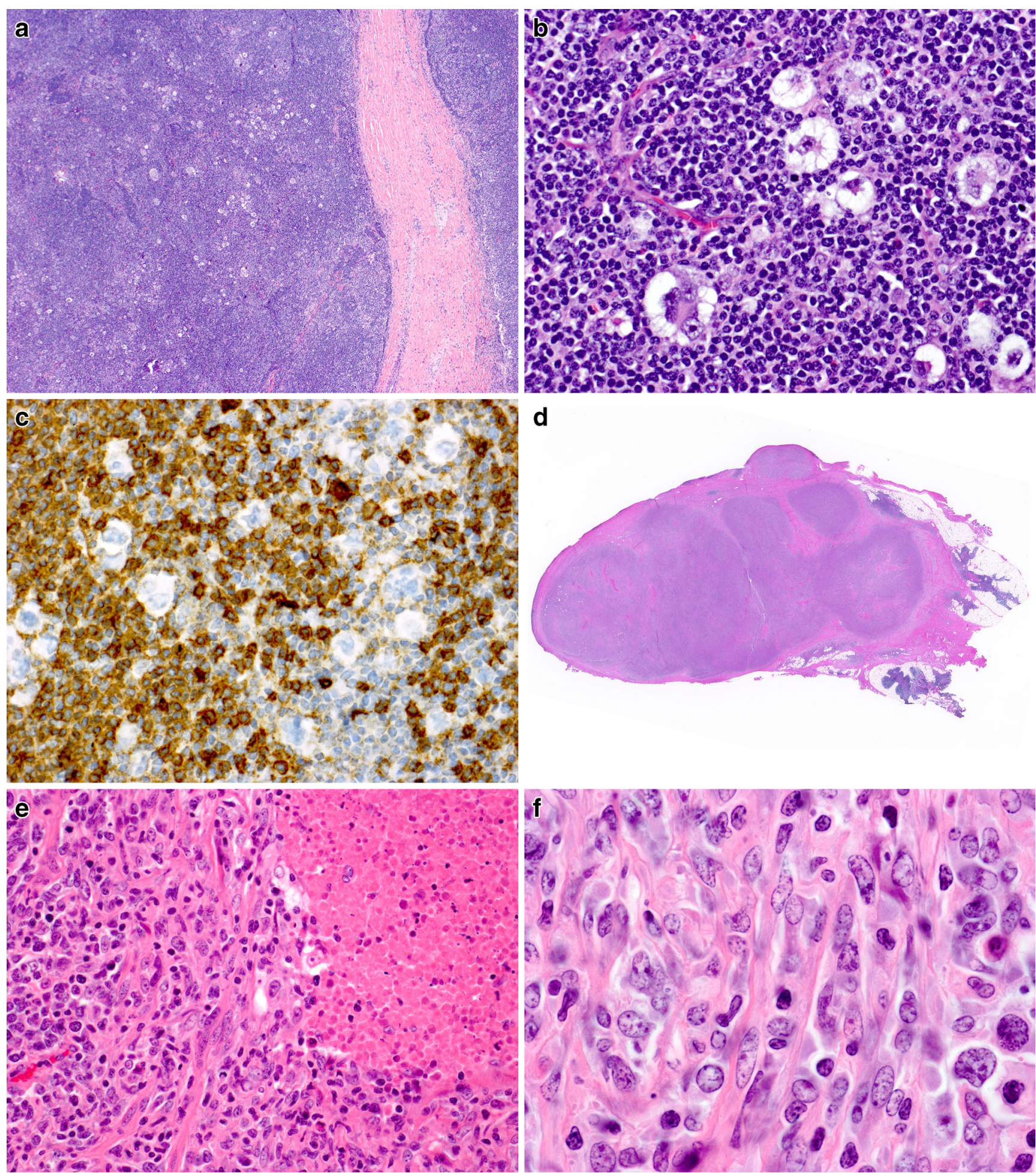

Fig. 3 Nodular sclerosis classical Hodgkin lymphoma (a-c), followed 3 years later by mediastinal large B cell lymphoma $(\mathbf{d}-\mathbf{i})$. a Low power of NSCHL shows tissue rich in small dark lymphocytes transected by a well-formed fibrous band. b High power shows lacunar cells, including multinucleated forms, with prominent cytoplasmic retraction in a background of small lymphocytes. c Neoplastic cells are negative for CD20 (shown here); other immunophenotypic features were also typical for CHL. d Whole mount of a section involved by mediastinal large B cell lymphoma shows cellular nodules separated by fibrous bands. Dark

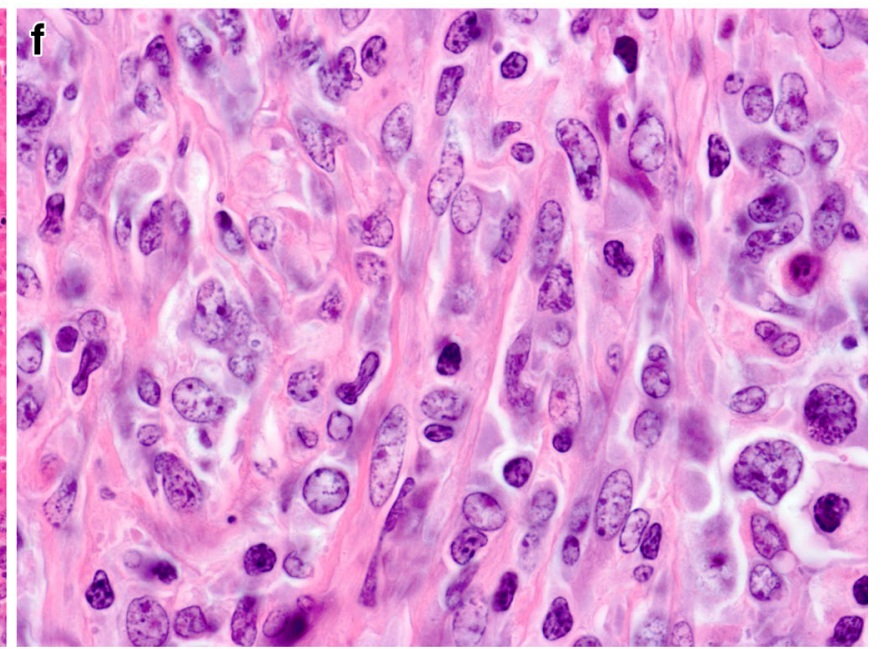

strands of thymic tissue are in continuity with the lesion (right). e The lymphoma had patchy areas of necrosis; ghosts of tumor cells are seen but granulocytes are absent from the necrosis. f Neoplastic cells have oval to lobated nuclear contours, mostly lack prominent nucleoli and are associated with delicate interstitial sclerosis. Admixed reactive cells are sparse. g Neoplastic cells show diffuse, strong staining for CD20, in contrast to the prior NSCHL (see c). h Neoplastic cells show partial, dim expression of CD30. i Some neoplastic cells show bright, dot-like Golgi region staining for $\mathrm{CD} 15$ 


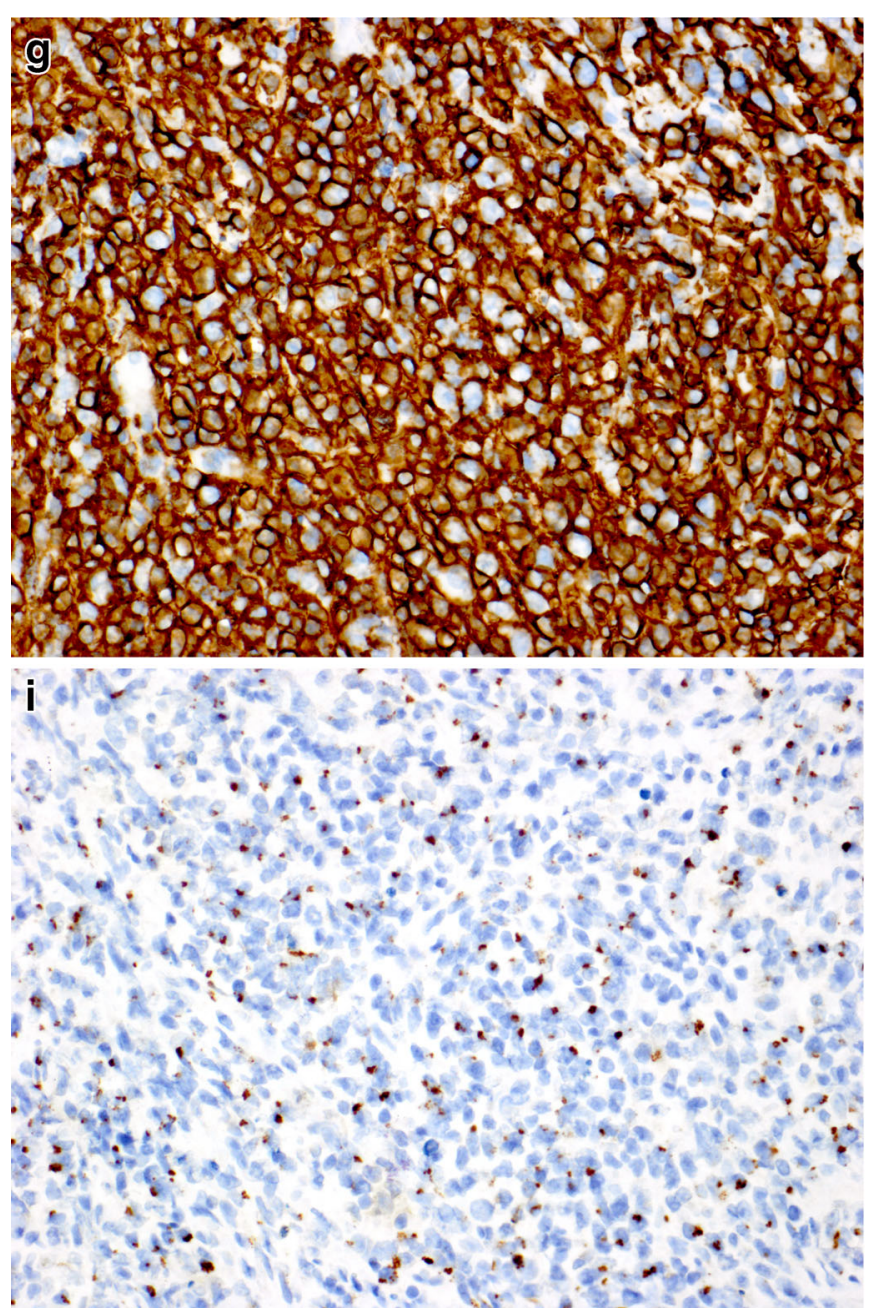

Fig. 3 (continued)

large anterior-superior mediastinal mass, including shortness of breath, chest pain, superior vena cava syndrome, or a combination of these. Constitutional symptoms are not common [47, 49, 51-54].

The lymphoma is composed of a diffuse infiltrate of large atypical lymphoid cells that is typically associated with sclerosis. The sclerosis can be coarse or fine, band-like or interstitial, or it can surround nests of cells, in a packeting pattern [55]. The appearance of the neoplastic cells varies from case to case, but they often have irregular, lobated nuclei and clear cytoplasm [56]. Neoplastic cells may also have round to oval nuclei and inconspicuous to prominent nucleoli, resembling centroblasts or immunoblasts (Fig. 3d-i). Neoplastic cells occasionally resemble Reed-Sternberg cells or mononuclear variants $[47-49,56]$. The neoplastic cells are typically diffusely positive for CD45 and for pan B cell markers (CD19, CD20, CD22, Pax5, and CD79a) (Fig. 3g) and co-express Oct-2 and BOB.1. Most cases lack surface immunoglobulin $[47,49,57,58]$. Expression of CD30 is common (Fig. 3h), but staining is usually weaker and more variable than in $\mathrm{CHL}$ [57-59]. CD15 expression, especially in the form of dot-like

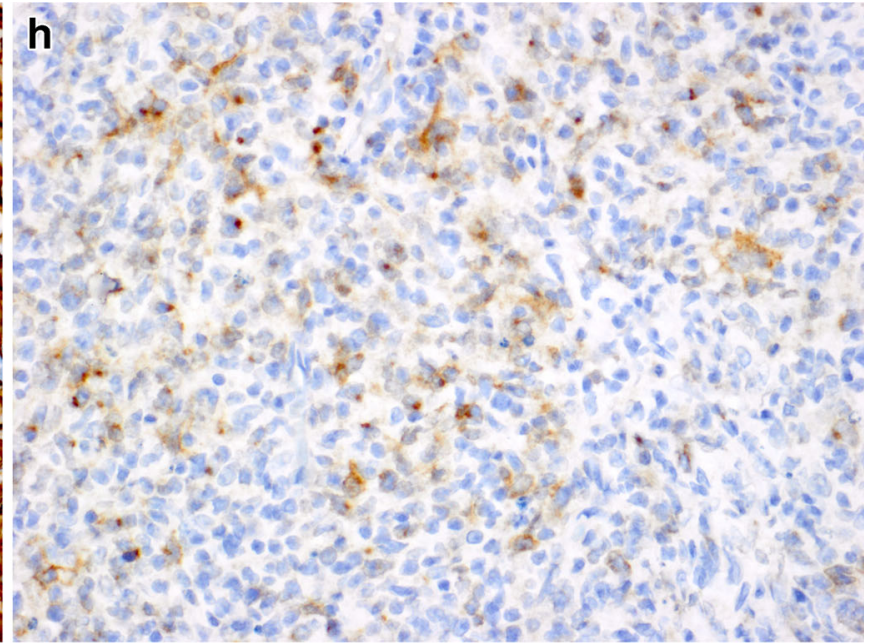

Golgi region staining in a subset of cells, is common (Fig. 3i) [60], but strong staining of most neoplastic cells, or membrane staining, is very unusual.

NSCHL has clinical and pathological features that overlap with mediastinal large B cell lymphoma, including a tendency to affect younger adults, with a modest female preponderance, taking the form of mediastinal neoplasms with sclerosis. Both lymphomas are of $\mathrm{B}$ cell origin and share some immunophenotypic characteristics. The two lymphomas share some cytogenetic abnormalities, including frequent gains in 2p13-p16 and 9p24 (location of REL and JAK2, respectively) [40], as well as similar abnormalities in gene expression profiles [61, 62]. Both lymphomas show activation of the NF- $\mathrm{KB}$ pathway which is considered critical in pathogenesis [39].

Despite these shared features, it is usually straightforward to distinguish NSCHL from mediastinal large B cell lymphoma if a well-preserved, optimally representative biopsy specimen of reasonable size is submitted for review. Supporting a diagnosis of Hodgkin lymphoma are an admixture of many reactive cells, especially eosinophils; neoplastic cells with an 
appearance convincing for Reed-Sternberg cells and variants; CD15 expression by tumor cells; diffuse bright CD30 expression by tumor cells; absence or weak, variable expression of $B$ cell antigens (CD20, CD79a) on tumor cells; dim Pax5 expression in tumor cells; and absence of CD45 on tumor cells. In favor of mediastinal large B cell lymphoma are the presence of diffuse, strong staining for CD45, pan B cell markers, Oct2, and BOB.1; absence of diffuse, bright CD30 expression on neoplastic cells; absence of diffuse, bright CD15 on neoplastic cells; and presence of at most a subset of neoplastic cells with morphology resembling Reed-Sternberg cells and variants. Tumor cells in mediastinal large B cell lymphoma typically grow in sheets, with relatively few admixed reactive cells, but if the biopsy is taken from the periphery of the lesion, there may be an increased proportion of reactive cells, mainly small T cells.

Rare patients have developed both mediastinal large B cell lymphoma and CHL, synchronously or metachronously (Fig. 3) [63]. The shared clinical and pathological features of these two lymphomas suggest that they are related entities, possibly sharing a common cell of origin and a similar pathogenesis.

Primary mediastinal gray-zone lymphoma is another important entity in the differential of NSCHL. The term "primary mediastinal gray-zone lymphoma" is used for cases of B cell lymphoma, unclassifiable, with features intermediate between diffuse large B cell lymphoma (in particular, primary mediastinal large B cell lymphoma) and CHL arising in the mediastinum [64]. As can be concluded by this designation, subclassification of these cases is often problematic [11, 63, 65]. Tumor cells are usually abundant, often growing in sheets. Neoplastic cells are large and atypical and often resemble Reed-Sternberg cells and mononuclear variants, including lacunar cells. Some cases have a component of neoplastic cells with the appearance of centroblasts and immunoblasts. The appearance of the neoplastic cells can vary from one area of the tumor to another. Reactive cells are less abundant than in the usual case of NSCHL, but cells present may include small lymphocytes, histiocytes, and even eosinophils. Necrosis, when present, does not contain neutrophils, in contrast to CHL. Associated fibrosis is common; it may be diffuse, irregular, or band-like [64]. The immunophenotype typically overlaps with that found in CHL, but with better preservation of the B cell differentiation program than usually seen in CHL. Thus, neoplastic cells are often $\mathrm{CD} 30+$ and $\mathrm{CD} 15+$, with CD45, CD20, Pax5, Oct-2, and BOB.1 also often expressed. ALK and immunoglobulin, by definition, are not expressed. Epstein-Barr virus (EBV) is reported as present using in situ hybridization for EBER in $20 \%$ of all B cell lymphoma, unclassifiable, with features intermediate between diffuse large B cell lymphoma and CHL [64]; however, in mediastinal gray-zone lymphomas, EBV is typically absent. It is possible that at least some EBV+ large cell lymphomas previously designated as gray-zone lymphomas would be better subclassified as EBV+ diffuse large B cell lymphoma of the elderly.

Mediastinal gray-zone lymphoma tends to behave in an aggressive manner, and the best therapy remains to be identified $[11,66,67]$.

\section{Mixed cellularity classical Hodgkin lymphoma}

Mixed cellularity classical Hodgkin lymphoma (MCCHL) accounts for 20 to $25 \%$ of cases of Hodgkin lymphoma. It is more frequent in developing countries and in HIV-positive patients. This disorder may affect patients of any age, but in developed countries, it is most common in older adults. Characteristically, there are frequent classic Reed-Sternberg cells and variants in a background that may include irregular coarse or fine interstitial fibrosis without fibrous band formation and an admixture of a variety of different types of reactive cells. This is the type of Hodgkin lymphoma most strongly associated with the presence of EBV. The majority of cases are positive for EBV [68].

\section{Lymphocyte-rich classical Hodgkin lymphoma}

Lymphocyte-rich classical Hodgkin lymphoma (LRCHL) accounts for $5 \%$ of all cases of Hodgkin lymphoma. Males are affected more often than females. Patients have localized disease generally involving peripheral lymph nodes without bulky disease or B symptoms. Histologic examination reveals a nodular or less often a diffuse growth. In the nodular type, the nodules typically consist of follicles with expanded mantles, sometimes with remnants of follicle centers. The follicle centers may be small and hyalinized. Neoplastic cells are scattered in the interfollicular region and within the expanded mantles of the follicles. The background consists almost exclusively of lymphocytes and histiocytes.

The main entity in the differential diagnosis of LRCHL, because of the nodular pattern and monotonous background population, is NLPHL. Follicle centers within cellular nodules are less commonly found in NLPHL than in LRCHL. The morphology and immunophenotype of the neoplastic cells are more like those of CHL than those of NLPHL [13, 69]. In one study comparing LRCHL with NLPHL and other types of CHL, however, the authors observed more frequent expression of CD20, bcl6, Oct-2, and BOB.1 in LRCHL than in other CHL. Expression of MUM1/IRF4 was more common and expression of CD20, bcl6, Oct-2, and BOB.1+ less common in LRCHL than in NLPHL. PD1+ CD57+ T cell rosettes were found in some cases of LRCHL, but less often than in NLPHL. The authors concluded that LRCHL had features intermediate between other types of CHL and NLPHL [28]. 


\section{Lymphocyte-depleted classical Hodgkin lymphoma}

Lymphocyte-depleted classical Hodgkin lymphoma (LDCHL) is the least common type of Hodgkin lymphoma, accounting for $<1 \%$ of cases of Hodgkin lymphoma. It was probably over-diagnosed in the past, but modern immunophenotyping techniques have allowed us to recognize that many cases so diagnosed were actually non-Hodgkin lymphoma, in particular diffuse large B cell lymphoma and anaplastic large cell lymphoma. This type of Hodgkin lymphoma tends to occur in older patients and HIV-positive patients and in individuals in developing countries. Hodgkin lymphoma of nodular sclerosis or mixed cellularity type at relapse may resemble lymphocyte-depleted Hodgkin lymphoma. Patients have widespread disease in most cases; traditionally, the disease is said to involve abdominal lymph nodes, liver, spleen, and marrow, sometimes without peripheral adenopathy, although in a study of eight cases of LDCHL performed in our laboratory, most patients presented with peripheral lymphadenopathy which was, in some cases, accompanied by more widespread disease [70]. The ReedSternberg cells may have the typical morphology, or they may have a bizarre sarcomatous appearance. Reactive cells are proportionally decreased in number while fibrosis and necrosis are often prominent. Immunophenotypic features are similar to those of other types of CHL. In our study, all four cases tested by whole section PCR showed clonal IGH@ rearrangement, likely related to the large proportion of neoplastic cells [70]. Traditionally, a poor prognosis has been associated with this type of Hodgkin lymphoma, but with optimal therapy, the prognosis is similar to that of other patients with Hodgkin lymphoma with same stage disease [71].

\section{Classical Hodgkin lymphoma: differential diagnosis}

The differential diagnosis of CHL is broad (Table 3). When reactive cells are abundant in cases of Hodgkin lymphoma, the differential diagnosis includes reactive hyperplasia as well as certain types of non-Hodgkin lymphoma. Perhaps the most common entity in the differential diagnosis is non-specific reactive hyperplasia with a component of immunoblasts. In such cases, architectural preservation, lack of convincing Reed-Sternberg cells, and lack of large lymphoid cells expressing both CD15 and CD30 support a reactive process. Of note, normal immunoblasts are often $\mathrm{CD} 30+$. In both cytomegaloviral lymphadenitis and infectious mononucleosis, there may be virus-infected large cells that closely resemble Reed-Sternberg cells. However, the background is that of a reactive lymph node without the effacement of the architecture usually seen in Hodgkin lymphoma. In infectious mononucleosis, the background lymphoid component consists of lymphocytes that are rather polymorphous, with a range of size in contrast to the lymphocytes in Hodgkin lymphoma that are nearly always uniformly small. Because Hodgkin lymphoma can be associated with changes resembling Castleman disease [72] and with granulomatous inflammation, lymph nodes showing these changes should be examined carefully to be certain that no Reed-Sternberg cells or variants are lurking in and among the hyaline-vascular follicles and the granulomas.

Peripheral $\mathrm{T}$ cell lymphomas may occasionally contain a population of Reed-Sternberg-like B cells. In such cases, the Reed-Sternberg-like B cells usually harbor EBV and express CD30 and sometimes, CD15 [73]. The most common T cell lymphoma to mimic Hodgkin lymphoma in this manner is angioimmunoblastic T cell lymphoma (AITL). AITL typically has an admixture of reactive cells, including eosinophils and plasma cells, and may mimic, in particular, MCCHL. Less commonly, peripheral T cell lymphoma, NOS [74], and rarely adult T cell leukemia/lymphoma (HTLV1+) $[74,75]$ contain Reed-Sternberg-like B cells. Recently, cases of the follicular variant of peripheral $\mathrm{T}$ cell lymphoma, NOS, which has a less polymorphous composition, and may also contain EBV+ Reed-Sternberg-like B cells have been described that have been mistaken initially for LRCHL [76]. Clues to the correct diagnosis in such cases include clinical and pathological features that would be unusual for CHL. In these T cell lymphomas, the neoplastic $T$ cells are likely to be atypical, with slightly enlarged, slightly irregular nuclei, in contrast to the small, bland lymphocytes seen in Hodgkin lymphoma. However, neoplastic $\mathrm{T}$ cells may show only subtle atypia, and careful study of well-prepared sections may be required to detect morphologic abnormalities. Immunophenotyping with immunohistochemistry or flow cytometry may be helpful in detecting abnormal $\mathrm{T}$ cell populations. In addition, $\mathrm{T}$ cell receptor gene rearrangement studies usually disclose a clonal $\mathrm{T}$ cell population in $\mathrm{T}$ cell lymphomas, while clonal $\mathrm{T}$ cells are nearly always absent in Hodgkin lymphoma. Unusual clinical features such as widespread disease or involvement of extranodal sites typically spared by Hodgkin lymphoma may also raise suspicion that Hodgkin lymphoma is not the correct diagnosis [76].

$\mathrm{T}$ cell/histiocyte-rich large B cell lymphoma can also be considered in the differential diagnosis of CHL. The neoplastic cells in T cell/histiocyte-rich large B cell lymphoma only occasionally resemble Reed-Sternberg cells. They usually more closely resemble centroblasts or immunoblasts. They have the immunophenotype of B cells in that they express CD20 and CD45 strongly and uniformly, in contrast to the immunophenotype of the Reed-Sternberg cells in CHL. The background population consists almost entirely of small lymphocytes with a variable number of admixed histiocytes, with very few admixed plasma cells or granulocytes as is usually seen in CHL. EBV is present in a subset of Hodgkin lymphoma but is typically absent in cases of $\mathrm{T}$ cell/histiocyte-rich large B cell lymphoma, so that the presence of EBV would 
Table 3 Classical Hodgkin lymphoma: differential diagnosis

\begin{tabular}{|c|c|c|}
\hline Diagnosis & Problem & Clues to diagnosis \\
\hline $\begin{array}{l}\text { Reactive lymphoid hyperplasia } \\
\text { (RLH) }\end{array}$ & $\begin{array}{l}\text { Paracortical hyperplasia may have CD30+ } \\
\text { immunoblasts in a mixed background of smaller } \\
\text { cells; immunoblasts may mimic mononuclear RS } \\
\text { variants }\end{array}$ & $\begin{array}{l}\text { Architecture may be distorted but is not obliterated in } \\
\text { RLH } \\
\text { Convincing RS cells are not seen } \\
\text { Immunoblasts are usually CD } 20+, \text { CD15-, and may } \\
\text { express polytypic Ig light chain }\end{array}$ \\
\hline Infectious mononucleosis (IM) & $\begin{array}{l}\text { EBV }+ \text { cells in IM may resemble RS cells and are often } \\
\text { CD30+ }\end{array}$ & $\begin{array}{l}\text { Architecture is distorted but not obliterated in IM } \\
\text { EBV-infected cells are typically CD20+, CD15- }\end{array}$ \\
\hline Cytomegaloviral lymphadenitis & CMV-infected cells may resemble RS cells & $\begin{array}{l}\mathrm{CMV}+\text { cells are typically present in a background of } \\
\text { florid follicular and monocytoid B cell hyperplasia } \\
\text { not resembling CHL }\end{array}$ \\
\hline $\begin{array}{l}\text { T cell/histiocyte-rich large B cell } \\
\text { lymphoma (THRBCL) }\end{array}$ & $\begin{array}{l}\text { Large atypical cells in a reactive background may } \\
\text { mimic CHL, especially LRCHL }\end{array}$ & $\begin{array}{l}\text { Large cells in THRBCL are typically } \mathrm{CD} 20+, \text { bcl6+, } \\
\text { CD15-, CD30-, and EBV-; this immunophenotype } \\
\text { excludes CHL }\end{array}$ \\
\hline $\begin{array}{l}\text { Mediastinal large B cell lymphoma } \\
\quad(\text { MLBCL) [55-60] }\end{array}$ & $\begin{array}{l}\text { Neoplastic cells of MLBCL have morphology that may } \\
\text { overlap with RS cells and variants and may express } \\
\text { CD30, mimicking NSCHL (especially the syncytial } \\
\text { variant) }\end{array}$ & $\begin{array}{l}\text { Tumor cells in MLBCL typically do not all resemble RS } \\
\text { cells and variants, and CD30 expression, when } \\
\text { present, is usually partial } \\
\text { Tumor cells in MLBCL are typically CD20+, CD } 45+\text {, } \\
\text { CD15- (or dot-like), Oct2+, Bob1+, and EBV-, in } \\
\text { contrast to CHL } \\
\text { Eosinophils are typically absent in MLBCL, but } \\
\text { common in CHL }\end{array}$ \\
\hline $\begin{array}{l}\text { Mediastinal gray-zone lymphoma } \\
\text { (MGZL) }[63,64]\end{array}$ & $\begin{array}{l}\text { MGZL is composed of numerous large atypical cells } \\
\text { with morphology overlapping with NSCHL } \\
\text { (especially the syncytial variant) and MLBCL; } \\
\text { immunophenotype may be intermediate between that } \\
\text { of CHL and DLBCL (CD20, CD30, and CD15 may } \\
\text { all be expressed) }\end{array}$ & $\begin{array}{l}\text { Establishing a diagnosis can be difficult. MGZL is a } \\
\text { possibility if there are morphologic and } \\
\text { immunophenotypic features intermediate between } \\
\text { CHL and DLBCL or there are a combination of those } \\
\text { of CHL and DLBCL }\end{array}$ \\
\hline $\begin{array}{l}\text { Anaplastic large cell lymphoma } \\
\text { (ALCL) }\end{array}$ & $\begin{array}{l}\text { The CD30+ neoplastic cells of ALCL may have } \\
\text { morphology mimicking RS cells and variants }\end{array}$ & $\begin{array}{l}\text { In favor of ALCL are sheet-like growth of tumor cells, } \\
\text { sinus involvement, presence of hallmark cells, T } \\
\text { antigen expression, expression of ALK, and absence } \\
\text { of Pax } 5 \\
\text { EBV+ tumor cells exclude ALCL } \\
\text { Clonal T cell population favors ALCL }\end{array}$ \\
\hline $\begin{array}{l}\text { Peripheral T cell lymphoma (PTCL) } \\
\text { with EBV+ large B cells [73-76] }\end{array}$ & $\begin{array}{l}\text { Some PTCLs, especially angioimmunoblastic TCL, } \\
\text { contain non-neoplastic EBV+ large B cells that re- } \\
\text { semble RS cells. If atypia of neoplastic T cells is } \\
\text { subtle, they may mimic CHL }\end{array}$ & $\begin{array}{l}\text { Presence of some cytologic atypia or abnormal } \\
\text { immunophenotype among T cells, or a clonal T cell } \\
\text { population by PCR favors PTCL }\end{array}$ \\
\hline $\begin{array}{l}\text { Lymph nodal involvement by } \\
\text { primary cutaneous CD } 30+\text { T cell } \\
\text { lymphoproliferative disorders } \\
\text { [79] }\end{array}$ & $\begin{array}{l}\text { Morphology may mimic CHL; CD30+ T cells may co- } \\
\text { express CD15, further mimicking CHL }\end{array}$ & $\begin{array}{l}\text { Expression of T cell antigens and lack of Pax } 5 \\
\text { expression by CD30+ cells, presence of clonal T cell } \\
\text { population by PCR, history of CD30+ cutaneous } \\
\text { lymphoma, presence of same clonal T cell } \\
\text { rearrangement in skin and lymph node would all } \\
\text { favor nodal involvement by CD30+ lymphoma } \\
\text { arising in skin over CHL }\end{array}$ \\
\hline
\end{tabular}

serve as evidence against a diagnosis of $\mathrm{T}$ cell/histiocyte-rich large B cell lymphoma [29, 77, 78].

When there is spread of certain primary cutaneous $\mathrm{T}$ cell lymphoproliferative disorders to lymph nodes, the appearance can closely mimic CHL, including expression of CD30, and often also CD15 by large atypical cells resembling ReedSternberg cells and mononuclear variants within the lymph node [79]. Clues to the diagnosis include history of cutaneous lymphoproliferative disorder (mycosis fungoides [especially with histologic progression/large cell transformation] or primary cutaneous $\mathrm{CD} 30+\mathrm{T}$ cell lymphoproliferative disorder), lack of Pax 5 expression by Reed-Sternberg-like cells, absence of EBV, presence of a clonal T cell population by PCR, and presence of the same $\mathrm{T}$ cell clone in lymph node and skin.

The differential diagnosis of cases of Hodgkin lymphoma with abundant neoplastic cells includes carcinoma, particularly well-differentiated thymic carcinoma in cases involving the mediastinum, melanoma, diffuse large B cell lymphoma, especially mediastinal large B cell lymphoma (see above), and anaplastic large cell lymphoma. On histologic examination, in 
favor of Hodgkin lymphoma would be the finding of neoplastic cells with convincing morphology for Reed-Sternberg cells and the finding of areas with an admixture of reactive cells characteristic of Hodgkin lymphoma. If a confident diagnosis cannot be made on histologic grounds, immunophenotyping can be extremely helpful. Carcinomas and thymic tumors express keratin. Thymic tumors may have $\mathrm{T}$ cells in the background with an immature immunophenotype $(\mathrm{CD} 1 \mathrm{a}+$ and $\mathrm{TdT}+)$. Melanomas express S-100, HMB45, and MART1. Mediastinal large B cell lymphoma and other large B cell lymphomas are positive for B antigens and the leukocyte common antigen. In anaplastic large cell lymphoma, a predominance of tumor cells and, in lymph nodes, sinusoidal growth, are more frequent than in Hodgkin lymphoma. Hodgkin lymphoma lacks the hallmark cells that are characteristic of anaplastic large cell lymphoma. Anaplastic large cell lymphoma, like Hodgkin lymphoma, is CD30+, but CD15 is less often expressed. CD45, one or more T cell antigens, and EMA are usually expressed in contrast to Hodgkin lymphoma. A subset of anaplastic large cell lymphomas is ALK-positive, while Hodgkin lymphoma is ALK-negative. Cytogenetic analysis reveals $\mathrm{t}(2 ; 5)$ involving $A L K$ and $N P M$ in most ALK+ anaplastic large cell lymphomas. Anaplastic large cell lymphomas lack EBV; clonal T cell receptor gene rearrangement can typically be demonstrated in ALK+ anaplastic large cell lymphoma.

Conflict of interest No financial support was provided for preparation of this work. No pertinent financial relationship exists. The author declares that she has no conflict of interest.

\section{References}

1. Hodgkin T (1832) On some morbid appearances of the absorbent glands and spleen. Med Chir Trans 17:68-114

2. Wilks S (1865) Cases of enlargement of the lymphatic glands and spleen (or Hodgkin's disease) with remarks. Guys Hosp Rep 11:56-67

3. Sternberg C (1898) Uber eine eigenartige unter dem Bilde der Pseudoleukamie verlaufende Tuberculose des lymphatischen Apparates. Ztschr Heilk 19:21-90

4. Reed D (1902) On the pathological changes in Hodgkin's disease, with special reference to its relation to tuberculosis. Johns Hopkins Hosp Rep 10:133-196

5. Stein H, Delsol G, Pileri S, Weiss L, Poppema S, Jaffe ES (2008) Classical Hodgkin lymphoma, introduction. In: Swerdlow S, Campo E, Harris N et al (eds) WHO classification tumours of haematopoietic and lymphoid tissues. IARC, Lyon, pp 326-329

6. Kuppers R, Engert A, Hansmann ML (2012) Hodgkin lymphoma. J Clin Investig 122:3439-3447

7. Kuppers R, Rajewsky K, Zhao M et al (1994) Hodgkin disease: Hodgkin and Reed-Sternberg cells picked from histological sections show clonal immunoglobulin gene rearrangements and appear to be derived from B cells at various stages of development. Proc Natl Acad Sci U S A 91:10962-10966

8. Steidl C, Connors JM, Gascoyne RD (2011) Molecular pathogenesis of Hodgkin's lymphoma: increasing evidence of the importance of the microenvironment. J Clin Oncol 29:1812-1826
9. Steidl C, Lee T, Shah SP et al (2010) Tumor-associated macrophages and survival in classic Hodgkin's lymphoma. N Engl J Med 362: $875-885$

10. Poppema S, Swerdlow S, Delsol G et al (2008) Nodular lymphocyte predominant Hodgkin lymphoma. In: Swerdlow S, Campo E, Harris $\mathrm{N}$ et al (eds) WHO classification tumours of haematopoietic and lymphoid tissues, 4th edn. IARC, Lyon, pp 323-325

11. Harris NL (2013) Shades of gray between large B-cell lymphomas and Hodgkin lymphomas: differential diagnosis and biological implications. Mod Pathol 26(Suppl 1):S57-S70

12. Shankar A, Daw S (2012) Nodular lymphocyte predominant Hodgkin lymphoma in children and adolescents - a comprehensive review of biology, clinical course and treatment options. Br J Haematol 159:288-298

13. Diehl V, Sextro M, Franklin J et al (1999) Clinical presentation, course, and prognostic factors in lymphocyte-predominant Hodgkin's disease and lymphocyte-rich classical Hodgkin's disease: report from the European Task Force on Lymphoma Project on lymphocyte-predominant Hodgkin's disease. J Clin Oncol 17:776783

14. Khoury JD, Jones D, Yared MA et al (2004) Bone marrow involvement in patients with nodular lymphocyte predominant Hodgkin lymphoma. Am J Surg Pathol 28:489-495

15. Seliem R, Ferry J, Hasserjian R, Harris N, Zukerberg L (2011) Nodular lymphocyte predominant Hodgkin lymphoma (NLPHL) with CD30 positive lymphocyte predominant (LP) cells. J Hematopathol 4:175-181

16. Prakash S, Fountaine T, Raffeld M, Jaffe ES, Pittaluga S (2006) IgD positive L\&H cells identify a unique subset of nodular lymphocyte predominant Hodgkin lymphoma. Am J Surg Pathol 30:585-592

17. Nicolae A, Huppmann A, Slack G et al (2013) EBV is infrequently expressed in the LP cells of nodular lymphocyte predominant Hodgkin lymphoma (NLPHL) in both children and adults. Mod Pathol 26:352A

18. Marafioti T, Hummel M, Anagnostopoulos I et al (1997) Origin of nodular lymphocyte-predominant Hodgkin's disease from a clonal expansion of highly mutated germinal-center B cells. N Engl J Med 337:453-458

19. Nam-Cha SH, Roncador G, Sanchez-Verde L et al (2008) PD-1, a follicular T-cell marker useful for recognizing nodular lymphocytepredominant Hodgkin lymphoma. Am J Surg Pathol 32:1252-1257

20. Rahemtullah A, Reichard KK, Preffer FI, Harris NL, Hasserjian RP (2006) A double-positive CD4+CD8+ T-cell population is commonly found in nodular lymphocyte predominant Hodgkin lymphoma. Am J Clin Pathol 126:805-814

21. Sohani AR, Jaffe ES, Harris NL, Ferry JA, Pittaluga S, Hasserjian RP (2011) Nodular lymphocyte-predominant Hodgkin lymphoma with atypical T cells: a morphologic variant mimicking peripheral T-cell lymphoma. Am J Surg Pathol 35:1666-1678

22. Fan Z, Natkunam Y, Bair E, Tibshirani R, Warnke RA (2003) Characterization of variant patterns of nodular lymphocyte predominant Hodgkin lymphoma with immunohistologic and clinical correlation. Am J Surg Pathol 27:1346-1356

23. Hartmann S, Eichenauer DA, Plutschow A et al (2013) The prognostic impact of variant histology in nodular lymphocyte-predominant Hodgkin lymphoma: a report from the German Hodgkin Study Group (GHSG). Blood 122:4246-4252

24. Hansmann M, Stein H, Fellbaum C, Hui P, Parwaresch M, Lennert K (1989) Nodular paragranuloma can transform into high-grade malignant lymphoma of B type. Hum Pathol 20:1169-1175

25. Huang J, Weisenberger D, Vose J et al (2003) Diffuse large B-cell lymphoma arising in nodular lymphocyte predominant Hodgkin lymphoma: a report of 21 cases from the Nebraska Lymphoma Study Group. Leuk Lymphoma 44:1903-1910

26. Al-Mansour M, Connors JM, Gascoyne RD, Skinnider B, Savage KJ (2010) Transformation to aggressive lymphoma in nodular 
lymphocyte-predominant Hodgkin's lymphoma. J Clin Oncol 28: 793-799

27. Ferry JA, Zukerberg LR, Harris NL (1992) Florid progressive transformation of germinal centers. A syndrome affecting young men, without early progression to nodular lymphocyte predominance Hodgkin's disease. Am J Surg Pathol 16:252-258

28. Nam-Cha SH, Montes-Moreno S, Salcedo MT, Sanjuan J, Garcia JF, Piris MA (2009) Lymphocyte-rich classical Hodgkin's lymphoma: distinctive tumor and microenvironment markers. Mod Pathol 22: 1006-1015

29. Boudova L, Torlakovic E, Delabie J et al (2003) Nodular lymphocyte-predominant Hodgkin lymphoma with nodules resembling T-cell/histiocyte-rich B-cell lymphoma: differential diagnosis between nodular lymphocyte-predominant Hodgkin lymphoma and T-cell/histiocyte-rich large B-cell lymphoma. Blood 102:3753-3758

30. Tousseyn T, De Wolf-Peeters C (2011) T cell/histiocyte-rich large Bcell lymphoma: an update on its biology and classification. Virchows Arch 459:557-563

31. Hartmann S, Doring C, Jakobus C et al (2013) Nodular lymphocyte predominant hodgkin lymphoma and $\mathrm{T}$ cell/histiocyte rich large $\mathrm{B}$ cell lymphoma - endpoints of a spectrum of one disease? PLoS One 8:e78812

32. Franke S, Wlodarska I, Maes B et al (2002) Comparative genomic hybridization pattern distinguishes T-cell/histiocyte-rich B-cell lymphoma from nodular lymphocyte predominance Hodgkin's lymphoma. Am J Pathol 161:1861-1867

33. Tzankov A, Bourgau C, Kaiser A et al (2005) Rare expression of Tcell markers in classical Hodgkin's lymphoma. Mod Pathol 18:15421549

34. Venkataraman G, Song JY, Tzankov A et al (2013) Aberrant T-cell antigen expression in classical Hodgkin lymphoma is associated with decreased event-free survival and overall survival. Blood 121:17951804

35. Anagnostopoulos I, Herbst H, Niedobitek G, Stein H (1989) Demonstration of monoclonal EBV genomes in Hodgkin's disease and Ki-1-positive anaplastic large cell lymphoma by combined Southern blot and in situ hybridization. Blood 74:810-816

36. Gandhi MK, Tellam JT, Khanna R (2004) Epstein-Barr virus-associated Hodgkin's lymphoma. Br J Haematol 125:267-281

37. Jarrett R (2003) Risk factors for Hodgkin's lymphoma by EBV status and significance of detection of EBV genomes in serum of patients with EBV-associated Hodgkin's lymphoma. Leuk Lymphoma 44: S27-S32

38. Marafioti T, Hummel M, Foss HD et al (2000) Hodgkin and ReedSternberg cells represent an expansion of a single clone originating from a germinal center B-cell with functional immunoglobulin gene rearrangements but defective immunoglobulin transcription. Blood 95:1443-1450

39. Rodig SJ, Savage KJ, Nguyen V et al (2005) TRAF1 expression and cRel activation are useful adjuncts in distinguishing classical Hodgkin lymphoma from a subset of morphologically or immunophenotypically similar lymphomas. Am J Surg Pathol 29:196-203

40. Weniger MA, Melzner I, Menz CK et al (2006) Mutations of the tumor suppressor gene SOCS-1 in classical Hodgkin lymphoma are frequent and associated with nuclear phospho-STAT5 accumulation. Oncogene 25:2679-2684

41. Navarro A, Diaz T, Martinez A et al (2009) Regulation of JAK2 by miR-135a: prognostic impact in classic Hodgkin lymphoma. Blood 114:2945-2951

42. Farrell K, Jarrett RF (2011) The molecular pathogenesis of Hodgkin lymphoma. Histopathology 58:15-25

43. Steidl C, Shah SP, Woolcock BW et al (2011) MHC class II transactivator CIITA is a recurrent gene fusion partner in lymphoid cancers. Nature 471:377-381

44. Stein $\mathrm{H}$, von Wasielewski R, Poppema S, MacLennan K, Guenova M (2008) Nodular sclerosis classical Hodgkin lymphoma. In: Swerdlow
S, Campo E, Harris N et al (eds) WHO classification tumours of haematopoietic and lymphoid tissues, 4th edn. IARC, Lyon, p 330

45. Ferry J, Linggood R, Convery K, Efird J, Eliseo R, Harris N (1993) Hodgkin's disease, nodular sclerosis type: implications of histologic subclassification. Cancer 71:457-463

46. van Spronsen DJ, Vrints LW, Erdkamp FLG, Grommelin MA, Dijkema I, et al (1995) Disappearance of prognostic value of subclassification of nodular sclerosing Hodgkin's disease in south-east Netherlands since 1972. Third International Symposium on Hodgkin's lymphoma, Koln, Germany:151A, 18-23 September 1995

47. Al-Sharabati M, Chittal S, Duga-Neulat I et al (1991) Primary anterior mediastinal B-cell lymphoma. Cancer 67:2579-2587

48. Cazals-Hatem D, Lepage E, Brice P et al (1996) Primary mediastinal large B-cell lymphoma. A clinicopathologic study of 141 cases compared with 916 nonmediastinal large B-cell lymphomas, a GELA ("Groupe d'Etude des Lymphomes de l'Adulte") study. Am J Surg Pathol 20:877-888

49. de Leval L, Ferry J, Falini B, Shipp M, Harris N (2001) Expression of bcl-6 and CD10 in primary mediastinal large cell lymphoma: evidence for derivation from germinal center B cells? Am J Surg Pathol 25:1277-1282

50. Joos S, Otano-Joos M, Ziegler S et al (1996) Primary mediastinal (thymic) B-cell lymphoma is characterized by gains of chromosomal material including 9p and amplification of the REL gene. Blood 87: $1571-1578$

51. Lazzarino M, Orlandi E, Paulli M et al (1997) Treatment outcome and prognostic factors for primary mediastinal (thymic) B-cell lymphoma: a multicenter study of 106 patients. J Clin Oncol 15:16461653

52. Savage KJ, Al-Rajhi N, Voss N et al (2006) Favorable outcome of primary mediastinal large B-cell lymphoma in a single institution: the British Columbia experience. Ann Oncol 17:123-130

53. Todeschini G, Secchi S, Morra E et al (2004) Primary mediastinal large B-cell lymphoma (PMLBCL): long-term results from a retrospective multicentre Italian experience in 138 patients treated with CHOP or MACOP-B/VACOP-B. Br J Cancer 90:372-376

54. Zinzani P, Martelli M, Bertini M et al (2002) Induction chemotherapy strategies for primary mediastinal large B-cell lymphoma with sclerosis: a retrospective multinational study on 426 previously untreated patients. Haematologica 87:1258-1264

55. Addis B, Isaacson P (1986) Large cell lymphoma of the mediastinum: a B-cell tumor of probable thymic origin. Histopathology 10 : 379-390

56. Paulli M, Strater J, Gianelli U et al (1999) Mediastinal B-cell lymphoma: a study of its histomorphologic spectrum based on 109 cases. Hum Pathol 30:178-187

57. Aisenberg AC (1999) Primary large cell lymphoma of the mediastinum. Semin Oncol 26:251-258

58. Savage KJ (2006) Primary mediastinal large B-cell lymphoma. Oncologist 11:488-495

59. Calaminici M, Piper K, Lee AM, Norton AJ (2004) CD23 expression in mediastinal large B-cell lymphomas. Histopathology 45:619-624

60. Bledsoe J, Hasserjian R, Soumerai J et al (2014) Immunohistochemical prognostic markers in primary mediastinal large B-cell lymphoma. Mod Pathol 27(Suppl 2):336A

61. Savage K, Monti S, Kutok J et al (2003) The molecular signature of mediastinal large B-cell lymphoma differs from that of other diffuse large B-cell lymphomas and shares features with classical Hodgkin lymphoma. Blood 102:3871-3879

62. Rosenwald A, Wright G, Leroy K et al (2003) Molecular diagnosis of primary mediastinal B cell lymphoma identifies a clinically favorable subgroup of diffuse large B-cell lymphoma related to Hodgkin lymphoma. J Exp Med 198:851-862

63. Traverse-Glehen A, Pittaluga S, Gaulard P et al (2005) Mediastinal gray zone lymphoma: the missing link between classic Hodgkin's 
lymphoma and mediastinal large B-cell lymphoma. Am J Surg Pathol 29:1411-1421

64. Jaffe E, Stein H, Swerdlow S, Campo E, Pileri S, Harris N (2008) Bcell lymphoma, unclassifiable, with features intermediate between diffuse large B-cell lymphoma and classical Hodgkin lymphoma. In: Swerdlow S, Campo E, Harris N et al (eds) WHO classification tumours of haematopoietic and lymphoid tissues, 4th edn. IARC, Lyon, pp 267-268

65. Ferry J (2014) The diversity of diffuse large B-cell lymphoma in extranodal sites: overview and update. J Hematopathol 7:57-70

66. Dunleavy K, Grant C, Eberle FC, Pittaluga S, Jaffe ES, Wilson WH (2012) Gray zone lymphoma: better treated like Hodgkin lymphoma or mediastinal large B-cell lymphoma? Curr Hematol Malig Rep 7: 241-247

67. Grant C, Dunleavy K, Eberle FC, Pittaluga S, Wilson WH, Jaffe ES (2011) Primary mediastinal large B-cell lymphoma, classic Hodgkin lymphoma presenting in the mediastinum, and mediastinal gray zone lymphoma: what is the oncologist to do? Curr Hematol Malig Rep 6: $157-163$

68. Weiss L, Von Wasielewski R, Delsol G, Poppema S, Stein H (2008) Mixed cellularity classical Hodgkin lymphoma. In: Swerdlow S, Campo E, Harris N et al (eds) WHO classification tumours of haematopoietic and lymphoid tissues. IARC, Lyon, p 331

69. Anagnostopoulos I, Isaacson P, Stein H (2008) Lymphocyte-rich classical Hodgkin lymphoma. In: Swerdlow S, Campo E, Harris N et al (eds) WHO classification tumours of haematopoietic and lymphoid tissues. IARC, Lyon, pp 332-333

70. Slack G, Ferry J, Hasserjian R et al (2009) Lymphocyte depleted Hodgkin lymphoma: an evaluation with immunophenotyping and genetic analysis. Leuk Lymphoma 50:1-7
71. Benharroch D, Stein H, Peh S-C (2008) Lymphocyte-depleted classical Hodgkin lymphoma. In: Swerdlow S, Campo E, Harris N et al (eds) WHO classification tumours of haematopoietic and lymphoid tissues. IARC, Lyon, p 334

72. Abdel-Reheim FA, Koss W, Rappaport ES, Arber DA (1996) Coexistence of Hodgkin's disease and giant lymph node hyperplasia of the plasma-cell type (Castleman's disease). Arch Pathol Lab Med 120:91-96

73. Quintanilla-Martinez L, Fend F, Rodriguez-Moguel L et al (1999) Peripheral T-cell lymphoma with Reed-Sternberg-like cells of B-cell phenotype and genotype associated with Epstein-Barr virus infection. Am J Surg Pathol 23:1233-1240

74. Nicolae A, Pittaluga S, Venkataraman G et al (2013) Peripheral T-cell lymphomas of follicular T-helper cell derivation with Hodgkin/ReedSternberg cells of B-cell lineage: both EBV-positive and EBVnegative variants exist. Am J Surg Pathol 37:816-826

75. Venkataraman G, Berkowitz J, Morris JC, Janik JE, Raffeld MA, Pittaluga S (2011) Adult T-cell leukemia/lymphoma with EpsteinBarr virus-positive Hodgkin-like cells. Hum Pathol 42:1042-1046

76. Moroch J, Copie-Bergman C, de Leval L et al (2012) Follicular peripheral T-cell lymphoma expands the spectrum of classical Hodgkin lymphoma mimics. Am J Surg Pathol 36:1636-1646

77. Jaffe E, Harris N, Stein H, Vardiman J (2001) Tumours of the haematopoietic and lymphoid tissues, 1st edn. IARC Press, Lyon

78. Lim M, Beaty M, Sorbara L et al (2002) T-cell/histiocyte-rich large B-cell lymphoma: a heterogeneous entity with derivation from germinal center B cells. Am J Surg Pathol 26:1458-1466

79. Eberle FC, Song JY, Xi L et al (2012) Nodal involvement by cutaneous CD30-positive T-cell lymphoma mimicking classical Hodgkin lymphoma. Am J Surg Pathol 36:716-725 